\title{
Transition from collision to subduction and its relation to slab seismicity and plate coupling
}

\author{
Ryuta Arai $^{i^{*}}$ and Takaya Iwasaki ${ }^{2}$
}

\begin{abstract}
The Philippine Sea plate exhibits an along-trench variation in structure, from an eastern volcanic arc to a typical oceanic crust in the west. The regional difference of intra-slab seismicity implies that this transition occurs around the Itoigawa-Shizuoka Tectonic Line (ISTL). However, the nature of the subducting slab in this region has not been studied in detail. Here, we investigate the structure of the Philippine Sea plate subducting beneath the ISTL. Using active source data, we found reflective portions at depths of 14-18 km. An amplitude evaluation for the reflection phases showed that the reflective zone has a $P$ wave velocity as low as $3.0 \mathrm{~km} / \mathrm{s}$. Together with its slightly northwestward-dipping geometry, we interpreted that the low-velocity zone is at the plate boundary and can be attributed to high water content supplied by the slab. This feature is in great contrast to the collision zone further east, where the slab top is less reflective and the dehydration process is inactive. This structural difference also correlates well with the regional distribution of slab seismicity. The reflective zones we found are likely located at the down-dip end of the locked zone, where high slip deficit rates are currently observed. This may suggest that changing fluid pressures and the resulting frictional properties in the down-dip direction control the transition from a coseismic rupture zone to a deeper aseismic zone.
\end{abstract}

Keywords: Nankai trough; Izu collision zone; Philippine Sea plate; Plate coupling; Frictional property; Wide-angle reflections

\section{Correspondence/findings Introduction}

It is well known that the Philippine Sea plate has strong along-trench structural variation reflecting its formation history (e.g., Okino et al. 1999). On its eastern flank, the Izu-Bonin volcanic arc, an intraoceanic island arc with crustal thickness of over $25 \mathrm{~km}$ (Kodaira et al. 2007), has developed along the volcanic front because of the subduction of the Pacific plate from the east (Stern et al. 2003) (Fig. 1). This volcanic arc has been colliding with the Honshu arc, forming the Izu arc-arc collision zone in central Japan (e.g., Aoike 1999). To the west, more typical oceanic crust with $5-10 \mathrm{~km}$ thickness, formed by back-arc opening, consists of the Shikoku basin and has been subducting at the Nankai trough (Kodaira et al. 2002, 2004; Nakanishi et al. 2008) (Fig. 1). A comparative study of these contrasting subduction structures of the Philippine Sea plate (Arai et al. 2014) suggested that

\footnotetext{
* Correspondence: ryuta@jamstec.go.jp

'Japan Agency for Marine-Earth Science and Technology, 3173-25

Showa-machi Kanazawa-ku, Yokohama, Kanagawa 236-0001, Japan Full list of author information is available at the end of the article
}

the original structure of the incoming plate controls water transportation deep into the mantle; oceanic basalts and mantle peridotites typically absorb fluids by hydrothermal circulation at spreading centers and/or seawater infiltration due to bending-related fractures and release them when subducted, while active volcanic arcs such as the Izu-Bonin arc lose these hydrous minerals in the process of crustal growth and volcanism.

This systematic variation in fluid distribution correlates well with the regional distribution of intra-slab seismicity; Seno and Yamasaki (2003) pointed out that, unlike the Nankai subduction zone, there is no intraslab seismicity beneath the Izu collision zone and indicated that the dehydration process is a controlling factor for the seismogenic process. This along-trench change in seismicity occurs suddenly at the Itoigawa-Shizuoka Tectonic Line (ISTL), a geological boundary between the northeast Japan and southwest Japan arcs, implying that the ISTL coincides spatially with the structural transition of the Philippine Sea plate from arc-like crust to oceanic crust. On the other hand, onshore seismic surveys and bathymetric features indicate that not oceanic crust but 

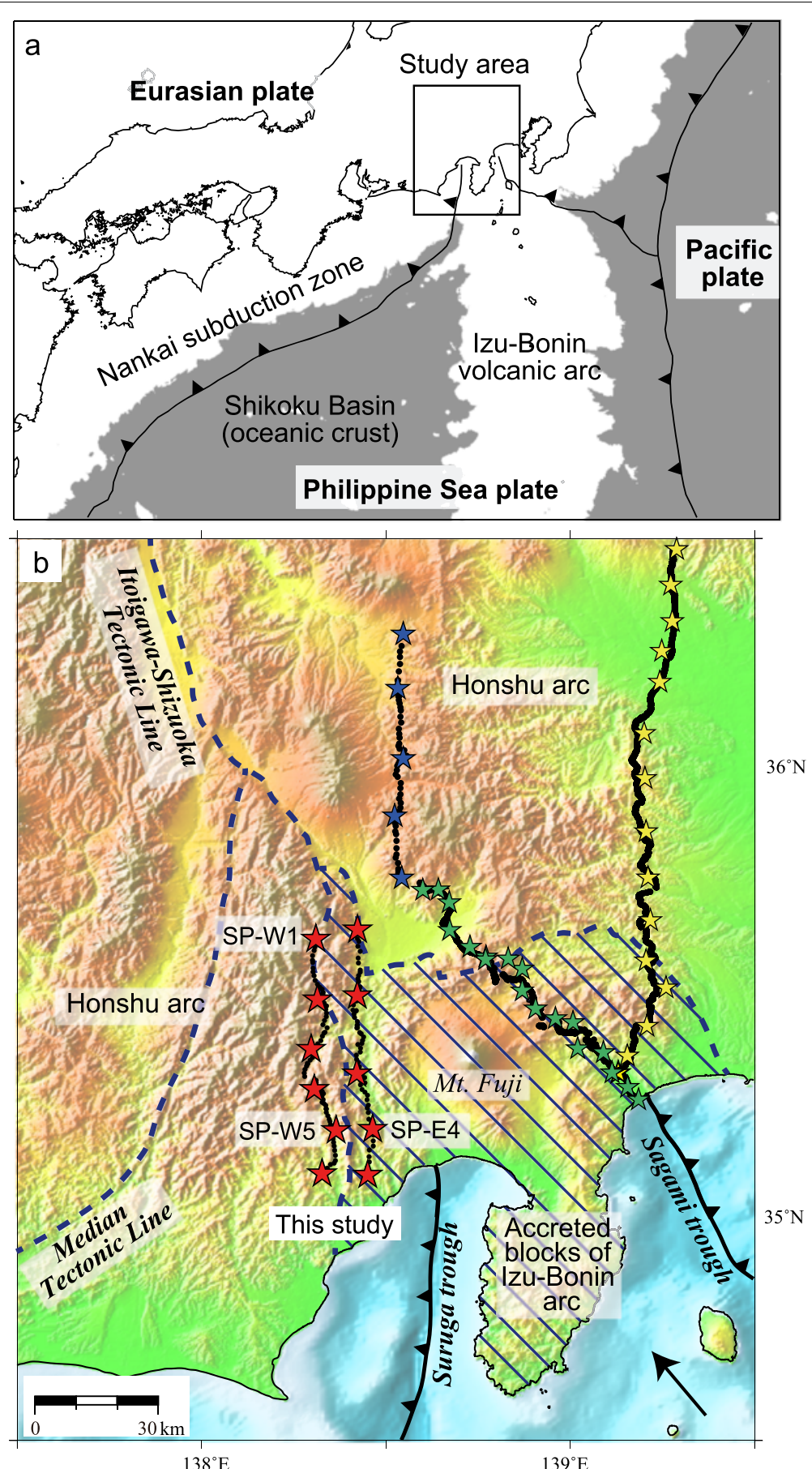

Fig. 1 a Tectonic map showing the study area. Gray areas delimit regions deeper than $3000 \mathrm{~m}$, highlighting the contrasting structure of the Philippine Sea plate between the Izu-Bonin volcanic arc and the Shikoku basin, consisting of typical oceanic crust. Black rectangle indicates location of plot (b). $\mathbf{b}$ Seismic experiments in and around the Izu collision zone. In this study, we used active-source data whose shot points are shown by red stars. Previous studies in the collision zone include seismic profiles whose shot points are indicated by yellow stars (Sato et al. 2005; Arai et al. 2009), green stars (Arai et al. 2013), and blue stars (Arai and Iwasaki 2014). Record sections of SP-W1, SP-W5, and SP-E4 are shown in Figs. 2 and 3. The Itoigawa-Shizuoka Tectonic Line (ISTL), Median Tectonic Line, and geological boundaries between the Izu-Bonin and Honshu arcs are shown by dashed blue lines. Geologically, the accreted Izu-Bonin arc blocks (hatched area) are delimited by the southernmost part of the ISTL. Black arrow indicates relative plate motion between the Philippine Sea plate and Eurasian plate (Seno et al. 1993). The GMT software (Wessel and Smith 1998) was used to draw the maps 
arc-like crust (several kilometers thicker than typical oceanic crust) exists just south of the ISTL (Nakanishi et al. 1998; Nishizawa et al. 2006; Kodaira et al. 2008), leaving the open question of the nature of the Philippine Sea plate subducting beneath the ISTL.

Several seismic experiments were carried out around the southernmost part of the ISTL in the last few decades (Research Group for Explosion Seismology 1988, 1992), and these experiments have the potential to constrain the eastern limit of the subduction system in the western Nankai subduction zone (Fig. 1). However, these seismic data were not fully examined in the context of the transition of the Philippine Sea plate mentioned above. In this paper, we reinterpret them in order to determine the nature of the slab and its relation to intraslab seismicity, especially in relation to the dehydration process within the oceanic lithosphere.

The Nankai subduction zone is also known as a seismogenic zone where large megathrust earthquakes have repeatedly occurred (e.g., Ando 1975). Around the southernmost ISTL, a strongly coupled zone outlined by geodetic measurements and seismic profiles used in this paper cross the zone where large slip deficit rates are currently observed (Suito and Ozawa 2009). Spatial variation in frictional properties along plate boundaries often appear as a difference in the seismic reflectivity of active source data; large-amplitude reflections are found in aseismic (conditionally stable) regions with weak plate coupling, while weakly reflective interfaces correspond to locked zones that rupture during a large earthquake (Kodaira et al. 2004; Nakanishi et al. 2004; Mochizuki et al. 2005). We used this correlation between the intensity of seismic reflections and frictional properties to investigate the structure atop the slab. Our seismic data provide insights on the down-dip end of the rupture zone along the plate interface in the easternmost Nankai subduction zone.

\section{Data and methods}

Two seismic experiments along the southernmost ISTL carried out by Research Group for Explosion Seismology (RGES) (Fig. 1) are expected to provide important structural constraints on the easternmost part of the area of high intraslab seismicity of the Philippine Sea plate; the eastern profile, laid out almost parallel to the ISTL, was carried out in 1983 (Research Group for Explosion Seismology 1988), and the western profile was performed in 1987 on the western side of the ISTL (Research Group for Explosion Seismology 1990, 1992) (Fig. 1b). Both seismic lines were approximately $60-\mathrm{km}$-long profiles and 71 (eastern profile) and 77 (western profile) stations were deployed along these lines. As seismic sources, five (eastern profile) and six (western profile) dynamite shots (with a charge of 300-700 kg) were fired. Seismic waves were recorded at a sampling rate of $100 \mathrm{~Hz}$ at all stations.

Figure 2a shows the seismic record section of SP-W1 (northernmost shot on the western profile), with the deep wide-angle reflections highlighted by a red arrow. Similar reflected waves are also recorded in SP-E4 (Fig. 2d) and SP-E5 (Fig. 3a). An important characteristic is their large amplitudes relative to those of the first arrivals, implying a large velocity jump across the corresponding reflector. These types of reflections are also seen in the western part of the Tokai (Kodaira et al. 2004; Iidaka et al. 2004) and Shikoku regions (Kurashimo et al. 2002; Kodaira et al. 2002), consistently suggesting the existence of a low-velocity layer along the plate boundary. On the other hand, such high-amplitude reflections are never observed in the Izu collision zone further east (Arai et al. 2009, 2014).

In order to explain these reflection phases, we constructed $P$ wave velocity models for both profiles by forward modeling using a ray tracing method (Iwasaki 1988). The $P$ wave velocity models for the upper $5 \mathrm{~km}$ of the crust were constructed from first arrivals. Then, the model was extrapolated to deeper parts using velocity models from other nearby active-source experiments (Arai et al. 2009; Arai and Iwasaki 2014) and regional passive-source tomography (Matsubara et al. 2008). Thereafter, we mapped a reflector using travel times of high-amplitude reflections. Finally, synthetic seismograms were calculated using the code SEIS83 (Červený and Pšenčík 1983) to evaluate the velocity contrast across the reflector.

\section{Results and discussions}

A distinct reflector was imaged at $14 \mathrm{~km}$ depth in the eastern profile (Fig. 2b) and $18 \mathrm{~km}$ depth in the western profile (Fig. 2e). Based on the misfit of travel times (within $0.1 \mathrm{~s}$ ) and the uncertainty of the velocity model $(0.5 \mathrm{~km} / \mathrm{s})$, we roughly estimated the error for the depth of the reflector to be less than $2.0 \mathrm{~km}$. To estimate the velocity contrast across the reflective zone, Fig. 2 compares observed seismic records of SP-W1 and SP-E4 with synthetic seismograms calculated by models in which a low-velocity layer with $\mathrm{Vp}=2.0-3.0 \mathrm{~km} / \mathrm{s}$ was assumed at depth. The thickness of the layer was assumed to be $100 \mathrm{~m}$ according to previous studies (e.g., Mochizuki et al. 2005). We see that the observed high-amplitude reflections are successfully reproduced by these models. Figure 3 examines other models by assuming different velocity values for the layer. We confirmed that the seismic record of SP-W5 also prefers a model with a low-velocity layer of $\mathrm{Vp}=3.0 \mathrm{~km} / \mathrm{s}$ (Fig. $3 \mathrm{a}-\mathrm{c}$ ). The synthetic seismograms from a model with $\mathrm{Vp}=4.0 \mathrm{~km} / \mathrm{s}$ may also be acceptable (Fig. 3d), implying that the velocity value for the layer includes a large error of up to $1.0 \mathrm{~km} / \mathrm{s}$. However, a model with $\mathrm{Vp}=6.0 \mathrm{~km} / \mathrm{s}$ (Fig. 3e) and no 


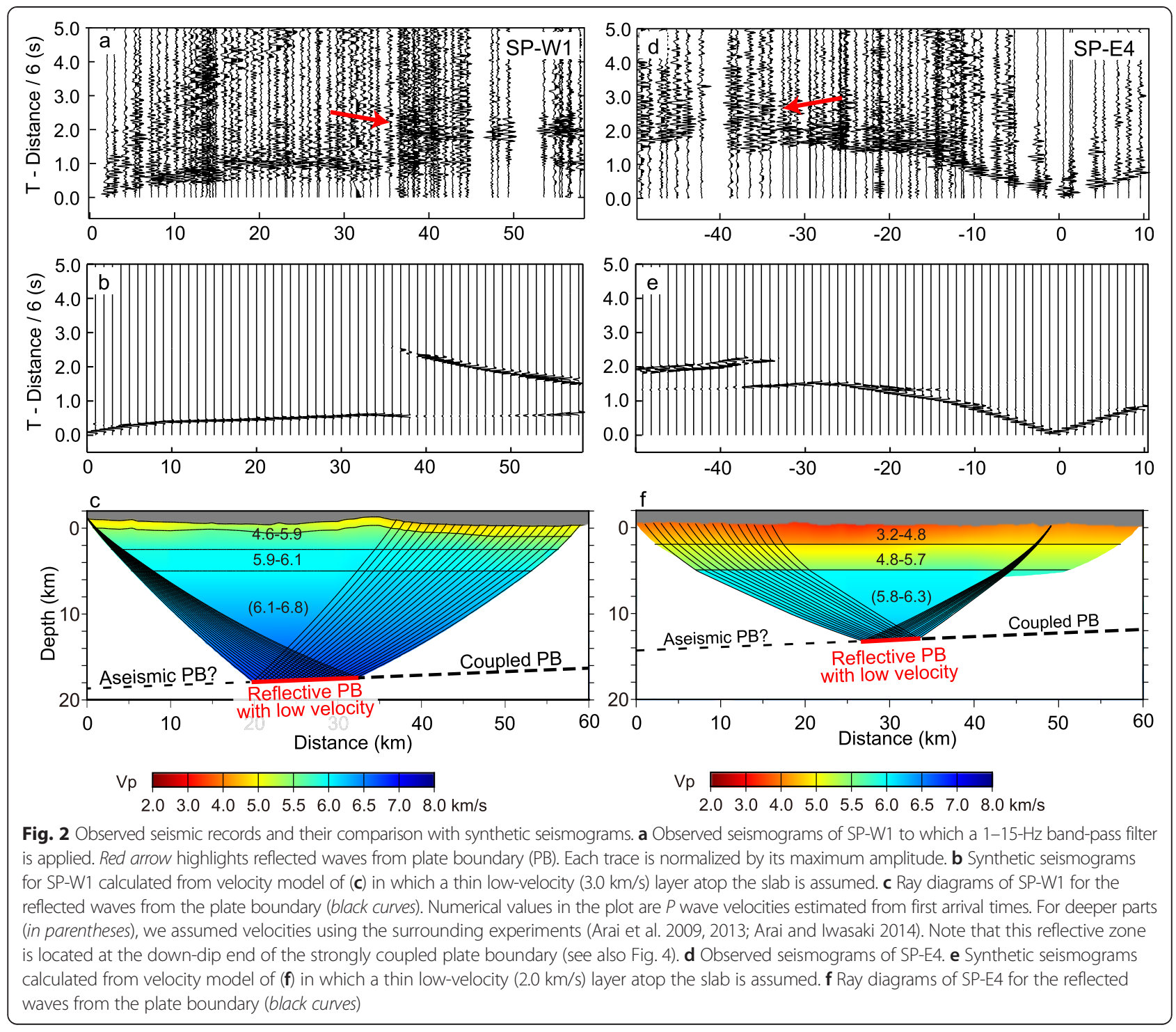

low-velocity zone (Fig. 3f) cannot explain the reduced amplitude of observed first arrivals.

Although the depth of the reflector in this study is 5-10 $\mathrm{km}$ shallower than the slab depth proposed by passivesource seismic data (e.g., Nakajima et al. 2009), the geometry (gently dipping northwestward) is consistent. This discrepancy may arise from the large uncertainty of the slab location in previous models because of its distorted geometry in this region and lack of deep seismicity in the Izu collision zone to the east. Together with the necessity for a low-velocity zone along the reflector as explained above, this suggests that the reflector is the top of the subducting Philippine Sea slab, forming a thin low-velocity layer. We also examined other interpretations for the reflector, such as the Moho occurring beneath the island arc and a mid-crustal reflector, and excluded both possibilities for the following reasons. First, the reflector we observed is located at $14-18 \mathrm{~km}$ depths, which is more than $15 \mathrm{~km}$ shallower than the Moho depth estimated in the study area (Kato et al. 2010; Katsumata 2010). Second, the velocity jump across the reflector needs to be more than 2.0 $\mathrm{km} / \mathrm{s}$. On the other hand, typical velocity contrasts at a mid-crustal reflector and Moho are less than $1.0 \mathrm{~km} / \mathrm{s}$ (Arai et al. 2009). Thus, it is unlikely that the reflector is either of these.

The estimated velocity values for the reflector $(2.0-4.0$ $\mathrm{km} / \mathrm{s}$ ) are consistent with those proposed by other seismic experiments in the Nankai subduction zone (Kodaira et al. 2002; Iidaka et al. 2004). According to Kodaira et al. (2002), a thin low-velocity layer lying between the subducting oceanic plate and the overriding landward plate has a high water content, expelled from the downgoing crust and/or serpentinized mantle. Although the seismic data in this study cannot constrain the internal structure of the slab, we 

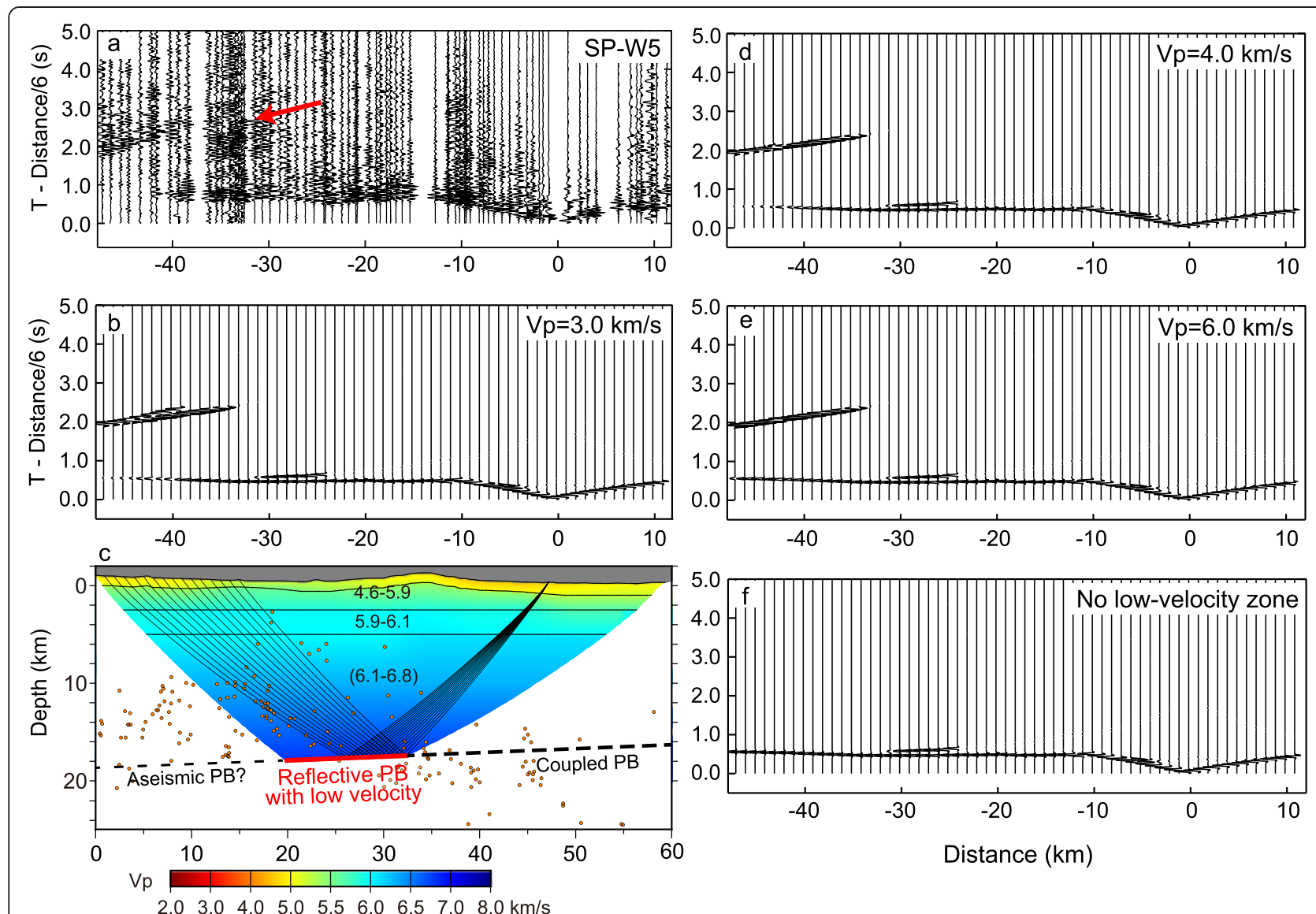

Fig. 3 a Observed seismograms of SP-W5 to which a 1-15-Hz band-pass filter is applied. Red arrow highlights reflected waves from plate boundary (PB). Each trace is normalized by its maximum amplitude. $\mathbf{b}$ Synthetic seismograms for SP-W1 calculated from velocity model of (c) in which a thin low-velocity $(3.0 \mathrm{~km} / \mathrm{s})$ layer atop the slab is assumed. $\mathbf{c}$ Ray diagrams of SP-W5 for the reflected waves from the plate boundary (black curves). Numerical values in the plot are $P$ wave velocities estimated from first arrival times. For deeper parts (in parentheses), we assumed velocities using the surrounding experiments (Arai et al. 2009, 2013; Arai and Iwasaki, 2014). For reference, we plotted earthquakes that occurred within 5 km of the seismic profile in 2007 and 2008 (orange dots). For the plot, we used hypocentral data from the unified catalog of the Japan Meteorological Agency. Synthetic seismograms calculated from a velocity model in which $4.0 \mathrm{~km} / \mathrm{s}(\mathbf{d}), 6.0 \mathrm{~km} / \mathrm{s}(\mathbf{e})$, and no low-velocity layer (f) is assumed for the PB. Note that a velocity model with a small (e) or no (f) velocity contrast at the PB cannot explain the reduced amplitudes of the first arrivals

speculate from the similarity in the reflection phases that the interpretation by Kodaira et al. (2002) is also true for the easternmost Nankai trough. Our interpretation of the reflective zone as having a high fluid content is supported by studies of electrical resistivity; a resistivity model by Aizawa et al. (2004) showed that a conductive zone exists just above the subducting Philippine Sea slab on the western side of Mt. Fuji, close to our study area, while such a body is not imaged on the eastern side. Matsubara et al. (2008) pointed out a similar contrast from regional seismic tomography, namely, the slab in the Nankai subduction zone, imaged as a zone with low $P$ wave and $S$ wave velocities and high $\mathrm{Vp} / \mathrm{Vs}$ ratios, indicates a high water content, while the subducting portion beneath the Izu collision zone is imaged as a high-velocity anomaly.

The aforementioned structural difference agrees well with the sudden increase in slab seismicity across the ISTL (Fig. 4a). On its eastern side, where the Izu-Bonin volcanic arc has been colliding/subducting and the slab top is less reflective, deep seismicity is rarely observed (Arai et al. 2014), while active seismicity is observed on its western side. Such spatial consistency between the seismicity and reflectivity on the plate boundary can be explained by the degree of dehydration within the subducting slab. Arai et al. (2014) indicated that the original structure of the incoming plate controls this systematic difference; oceanic crust and uppermost mantle subducting at the Nankai trough is typically enriched in hydrous minerals, such as blueschist and serpentinite, and releases fluids when subducted, while the crust derived from the Izu-Bonin arc has consumed most of the hydrous minerals for melt production before subduction, leading to inactive dehydration beneath the collision zone. This result implies that oceanic crust enriched in hydrous minerals has been subducting in this region rather than the arc-like crust. 


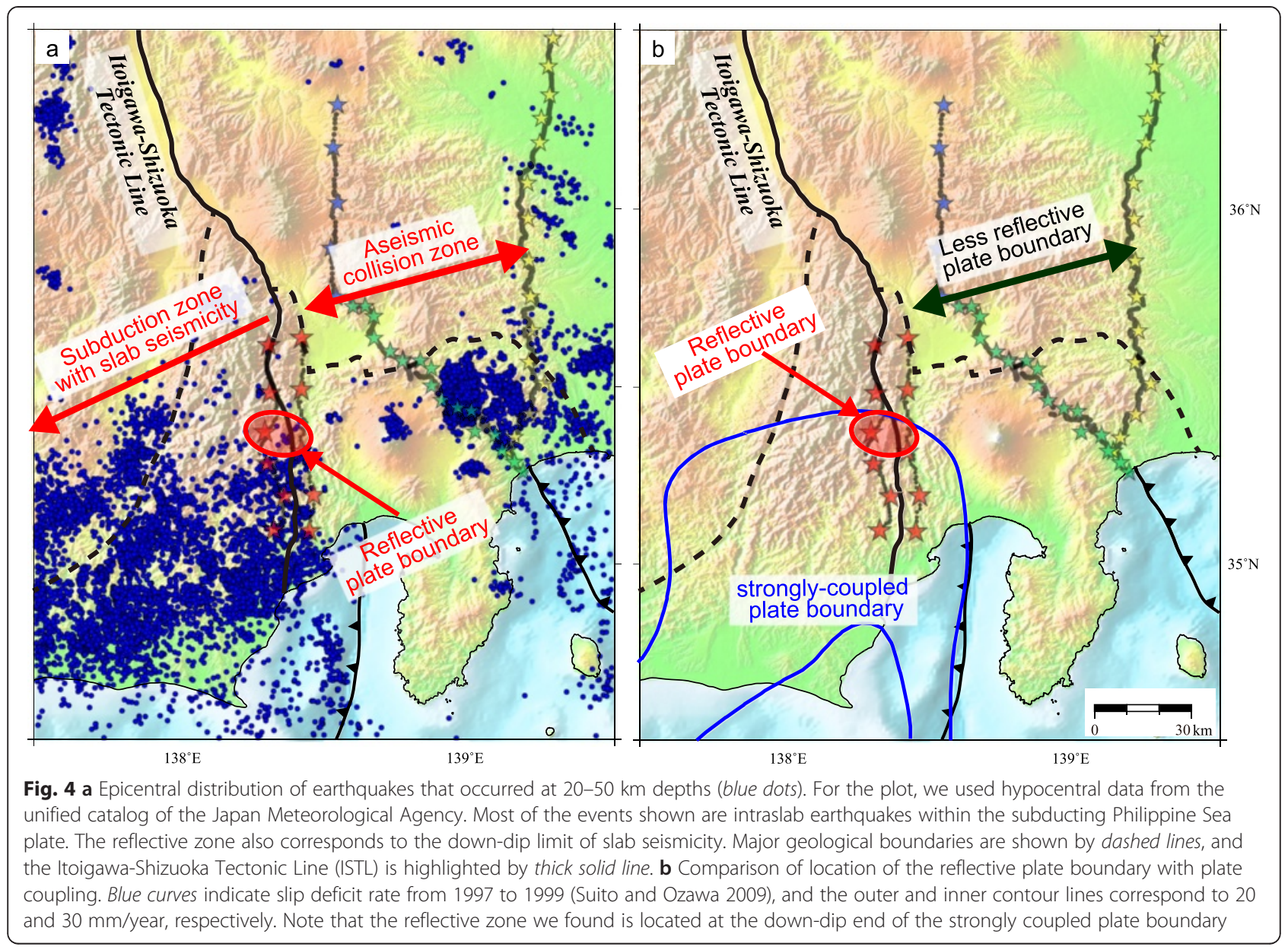

Our seismic data may provide another important constraint on the frictional property along the plate interface, since the seismic structure is closely correlated to interplate coupling (e.g., Fujie et al. 2013). In the easternmost Nankai subduction zone, a strongly coupled zone is outlined by geodetic measurements (Sagiya 1999; Suito and Ozawa 2009). The estimated slip deficit rate of $>20 \mathrm{~mm} /$ year, almost equivalent to the convergence rate between the overriding and subducting plates, implies that strain is being steadily accumulated at the contact, and will probably lead to coseismic rupture during a megathrust earthquake (Ando 1975). Our seismic lines in the north-south direction cross the transitional boundary between a strongly coupled zone and a weakly coupled zone along the plate boundary. The reflective zones we found are likely located close to the down-dip end of this locked zone (Fig. 4b). This spatial correlation may suggest that the reflective zone delimits the down-dip end of the coseismic rupture zone. Similar spatial patterns of seismic reflectivity (a shallow coseismic region with low reflectivity and a deeper aseismic region with relatively high reflectivity) are also observed in other areas of the
Nankai subduction zone (Kodaira et al. 2002, 2004; Iidaka et al. 2004). In the Tokai region further west of this study, Kodaira et al. (2004) correlated this reflective zone with the distribution of slow slips, and suggested that high-pressure fluids supplied by hydrous minerals within the slab effectively extend a region of stable slips, and consequently generate the slow slip. Changing fluid pressures and the resulting frictional properties in the down-dip direction probably control the transition from a coseismic rupture zone to a deeper aseismic zone.

The reflective zone we observed is $10-15 \mathrm{~km}$ wide in the down-dip direction, which is well constrained by the fact that high-amplitude reflections are not observed in shot records other than those shown in Figs. 2 and 3. In the western part of the Tokai region where the slow slips occur, the reflective zone is located at depths of approximately $30 \mathrm{~km}$ and is extended over a much broader region in the down-dip direction than in this study (Iidaka et al. 2004). The difference in slab depth must produce the difference in the nature of dehydration from the subducting plate and the frictional property along the plate boundary. 


\section{Conclusions}

We found a reflective zone at $14-18 \mathrm{~km}$ depths at the eastern end of the Nankai subduction zone. An amplitude evaluation of the reflections showed that the layer has a $P$ wave velocity as low as $3.0 \mathrm{~km} / \mathrm{s}$, which we interpreted as a low-velocity layer along the plate boundary that is probably enriched in fluids supplied by the subducting slab. The high-amplitude reflection phases are similar to those observed in other regions of the Nankai subduction zone and are in a great contrast to the Izu collision zone further east where the slab top is less reflective and the dehydration process is inactive. This structural difference also agrees well with the sudden increase in slab seismicity across the ISTL. Therefore, we suggest that, similar to the western Nankai subduction zone, the fluid-rich crust is subducting beneath the ISTL, and dehydrated fluids are enhancing the intraslab seismicity. The reflective zones we found are likely located at the down-dip end of the locked zone where high slip deficit rates are currently observed, which may suggest that the reflective zone with high water content delimits the down-dip end of the coseismic rupture zone.

\section{Competing interests}

The authors declare that they have no competing interests.

\section{Authors' contributions}

RA carried out the seismic modeling and drafted the manuscript. TI managed the seismic data and participated in the interpretation. Both authors read and approved the final manuscript.

\section{Acknowledgements}

We are grateful to the members of the Research Group for Explosion Seismology for the data acquisition. We also thank the editor and two anonymous reviewers for useful comments and the Japan Meteorological Agency for the hypocentral data. We used the GMT software (Wessel and Smith 1998) to draw the figures.

\section{Author details}

'Japan Agency for Marine-Earth Science and Technology, 3173-25

Showa-machi Kanazawa-ku, Yokohama, Kanagawa 236-0001, Japan.

${ }^{2}$ Earthquake Research Institute, The University of Tokyo, 1-1-1 Yayoi,

Bunkyo-ku, Tokyo 113-0032, Japan.

Received: 15 March 2015 Accepted: 14 May 2015

Published online: 27 May 2015

\section{References}

Aizawa K, Yoshimura R, Oshiman N (2004) Splitting of the Philippine Sea Plate and a magma chamber beneath Mt. Fuji Geophys Res Lett 31:L09603. doi:10.1029/2004GL019477

Ando M (1975) Possibility of a major earthquake in the Tokai district, Japan and its pre-estimated seismotectonic effects. Tectonophysics 25:69-85

Aoike K (1999) Tectonic evolution of the Izu collision zone. Res Rep Kanagawa prefect Mus Nat His 9:111-151

Arai R, Iwasaki T (2014) Crustal structure in the northwestern part of the Izu collision zone in central Japan. Earth Planets Space 66:21

Arai R, Iwasaki T, Sato H, Abe S, Hirata N (2009) Collision and subduction structure of the Izu-Bonin arc, central Japan, revealed by refraction/wide-angle reflection analysis. Tectonophysics 475:438-453

Arai R, Iwasaki T, Sato H, Abe S, Hirata N (2013) Crustal structure of the Izu collision zone in central Japan from seismic refraction data. J Geophys Res Solid Earth 118:6258-6268. doi:10.1002/2013JB010532
Arai R, Iwasaki T, Sato H, Abe S, Hirata N (2014) Contrasting subduction structures within the Philippine Sea plate: Hydrous oceanic crust and anhydrous volcanic arc crust. Geochem Geophys Geosyst 15:1977-1990. doi:10.1002/2014GC005321 Červený V, Pšenčík I (1983) Program package SEIS83. Charles University, Prague

Fujie G, Miura S, Kodaira S, Kaneda Y, Shinohara M, Mochizuki K, Kanazawa T, Murai Y, Hino R, Sato T, Uehira K (2013) Along-trench structural variation and seismic coupling in the northern Japan subduction zone. Earth Planets Space 65:75-83

lidaka T, Takeda T, Kurashimo E, Kawamura T, Kaneda Y, Iwasaki T (2004) Configuration of subducting Philippine Sea plate and crustal structure in the central Japan region. Tectonophysics 388:7-20

Iwasaki T (1988) Ray-tracing program for study of velocity structure by ocean bottom seismographic profiling. J Seismol Soc Jpn 41:263-266

Kato A, lidaka T, Ikuta R, Yoshida Y, Katsumata K, Iwasaki T, Sakai S, Thurber C, Tsumura N, Yamaoka K, Watanabe T, Kunitomo T, Yamazaki F, Okubo M, Suzuki S, Hirata N (2010) Variations of fluid pressure within the subducting oceanic crust and slow earthquakes. Geophys Res Lett 37:L14310. doi:10.1029/2010GL043723

Katsumata A (2010) Depth of the Moho discontinuity beneath the Japanese islands estimated by traveltime analysis. J Geophys Res 115:B04303. doi:10.1029/2008JB005864

Kodaira S, Kurashimo E, Park JO, Takahashi N, Nakanishi A, Miura S, Iwasaki T, Hirata N, Ito K, Kaneda Y (2002) Structural factors controlling the rupture process of a megathrust earthquake at the Nankai trough seismogenic zone. Geophys J Int 149:815-835

Kodaira S, lidaka T, Kato A, Park J, Iwasaki T, Kaneda Y (2004) High pore fluid pressure may cause silent slip in the Nankai trough. Science 304:1295-1298

Kodaira S, Sato T, Takahashi N, Ito A, Tamura Y, Tatsumi Y, Kaneda Y (2007) Seismological evidence for variable growth of crust along the Izu intraoceanic arc. J Geophys Res 112:B05104. doi:10.1029/2006JB004593

Kodaira S, Sato T, Takahashi N, Yamashita M, No T, Kaneda Y (2008) Seismic imaging of a possible paleoarc in the Izu-Bonin intraoceanic arc and its implications for arc evolution processes. Geochem Geophys Geosyst 9:Q10X01. doi:10.1029/ 2008GC002073

Kurashimo E, Tokunaga M, Hirata N, Iwasaki T, Kodaira S, Kaneda Y, Ito K, Nishida R, Kimura S, Ikawa T (2002) Geometry of the subducting Philippine Sea Plate and the crustal and upper mantle structure beneath eastern Shikoku Island revealed by seismic refraction/wide-angle reflection profiling. Zisin 54:489-505

Matsubara M, Obara K, Kasahara K (2008) Three-dimensional P-and S-wave velocity structures beneath the Japan Islands obtained by high-density seismic stations by seismic tomography. Tectonophysics 454:86-103

Mochizuki K, Nakamura M, Kasahara J, Hino R, Nishino M, Kuwano A, Nakamura Y, Yamada T, Shinohara M, Sato T, Moghaddam PP, Kanazawa T (2005) Intense PP reflection beneath the aseismic forearc slope of the Japan Trench subduction zone and its implication of aseismic slip subduction. J Geophys Res 110:B01302. doi:10.1029/2003JB002892

Nakajima J, Hirose F, Hasegawa A (2009) Seismotectonics beneath the Tokyo metropolitan area, Japan: Effect of slab-slab contact and overlap on seismicity. J Geophys Res 114:B08309. doi:10.1029/2008JB006101

Nakanishi A, Shiobara H, Hino R, Kodaira S, Kanazawa T, Shimamura H (1998) Detailed subduction structure across the eastern Nankai Trough obtained from ocean bottom seismograph profiles. J Geophys Res 103:27151-27168

Nakanishi A, Smith AJ, Miura S, Tsuru T, Kodaira S, Obana K, Takahashi N, Cummins PR, Kaneda Y (2004) Structural factors controlling the coseismic rupture zone of the 1973 Nemuro-Oki earthquake, the southern Kuril Trench seismogenic zone. J Geophys Res 109:B05305. doi:10.1029/2003JB002574

Nakanishi A, Kodaira S, Miura S, Ito A, Sato T, Park JO, Kido Y, Kaneda Y (2008) Detailed structural image around splay-fault branching in the Nankai subduction seismogenic zone: Results from a high-density ocean bottom seismic survey. J Geophys Res 113:B03105. doi:10.1029/2007JB004974

Nishizawa A, Kaneda K, Nakanishi A, Takahashi N, Kodaira S (2006) Crustal structure of the ocean-island arc transition at the mid Izu-Ogasawara (Bonin) arc margin. Earth Planets Space 58:e33-e36

Okino K, Ohara Y, Kasuga S, Kato Y (1999) The Philippine Sea: New survey results reveal the structure and the history of the marginal basins. Geophys Res Lett 26:2287-2290

Research Group for Explosion Seismology (1988) Explosion seismic observations in Yamanashi and Shizuoka Prefecture, Central Japan: Kushigata-Shimizu profile. Bull Earthq Res Inst Univ Tokyo 63:1-22

Research Group for Explosion Seismology (1990) Explosion seismic observations on Hayakawa-Shizuoka profile. Abstr Programs Seismol Soc Jpn 1:E11-07 
Research Group for Explosion Seismology (1992) Explosion seismic observations along the southern part of the Itoigawa-Shizuoka Tectonic Line, HayakawaShizuoka profile. Bull Earthq Res Inst Univ Tokyo 67:303-323

Sagiya T (1999) Interplate coupling in the Tokai District, Central Japan, deduced from continuous GPS data. Geophys Res Lett 26:2315-2318

Sato H, Hirata N, Koketsu K, Okaya D, Abe S, Kobayashi R, Matsubara M, Iwasaki T, Ito T, Ikawa T, Kawanaka T, Kasahara K, Harder S (2005) Earthquake source fault beneath Tokyo. Science 309:462-464

Seno T, Yamasaki T (2003) Low-frequency tremors, intraslab and interplate earthquakes in southwest Japan - from a view point of slab dehydration. Geophys Res Lett 30:2171. doi:10.1029/2003GL018349

Seno T, Stein S, Gripp AE (1993) A model for the motion of the Philippine Sea plate consistent with NUVEL-1 and geological data. J Geophys Res 98:17941-17948. doi:10.1029/93JB00782

Stern RJ, Fouch MJ, Klemperer SL (2003) An overview of the Izu-Bonin-Mariana subduction factory. In: Eiler J (ed) Inside the subduction factory. American Geophysical Union, Washington

Suito H, Ozawa T (2009) Transient crustal deformation in the Tokai district. J Seismol Soc Jpn 2(61):113-135

Wessel P, Smith WHF (1998) New improved version of the generic mapping tools released. Eos Trans AGU 79:579

\section{Submit your manuscript to a SpringerOpen ${ }^{\circ}$ journal and benefit from:}

- Convenient online submission

- Rigorous peer review

- Immediate publication on acceptance

- Open access: articles freely available online

- High visibility within the field

- Retaining the copyright to your article

Submit your next manuscript at $>$ springeropen.com 